\title{
MARKET ORIENTED APPROACH OF REVEALED COMPARATIVE ADVANTAGE IN INTERNATIONAL TRADE
}

\author{
Boris Kuzman', Milan Stegic ${ }^{2}$, Jonel Subićc
}

\begin{abstract}
Summary
Market oriented relative comparative trade advantage (MORTA) represents new approach to a widely accepted model of revealed comparative advantage (RCA) presented for the first time in this paper. The applied model was used in the analysis of agro-food trade in order to identify changes in the level of relative comparative trade advantage between the EU and Serbia before and during the implementation of the Stabilization and Association Agreement with the EU (2004-2013) on the basis of Eurostat data and data of the Statistical Office of the Republic of Serbia. The analysis aims to show whether Serbia and the EU, each on their side, were able to take advantage of the trade liberalization, especially in relative terms. The research results show that Serbia in terms of trade liberalization with the EU manages to secure the growth of the product with relative comparative trade advantage, but on the other side EU fails to largely use preferential status in trade with Serbia.
\end{abstract}

Key words: market oriented revealed comparative advantage, agro-food trade, EU, Serbia

JEL: $Q 17, F 14$

\section{Introduction}

As a result of the conflict in the former Socialist Federal Republic of Yugoslavia and in Kosovo and Metohija, the European Union (EU) offered new policy framework called Stabilization and Association Process as a clear perspective for Western Balkans countries towards EU accession. In terms of trade relations, Stabilization and Association Agreement (SAA) (Official Gazette, 83/2008) has been established in order to provide full liberalization

1 Boris Kuzman, Ph.D., Institute of Agricultural Economics, Volgina Street no. 15, 11060 Belgrade, Serbia, Phone: +381 63 590129, E-mail: kuzmanboris@yahoo.com

2 Milan Stegić, M.sci., Ph.D. student, Faculty of Economics and Engineering Management, Cvećarska street No.2, 21000 Novi Sad, Serbia, Phone: +381 63 8998804, E-mail: stegicmilan@gmail.com

3 Jonel Subić, Ph.D., Institute of Agricultural Economics, Volgina Street no. 15, 11060 Belgrade, Serbia, Phone: +381 63 296111, E-mail: jonel_s@iep.bg.ac.rs

EP 2016 (63) 1 (247-260) 
of trade relations ${ }^{4}$. Serbia, as a state in which the agro-food sector is more important than the EU average (Strategy of agriculture and rural development, 2014), strived to take full advantage of the export liberalization to the EU as its most important market, but was also concerned by the liberalization of import regime in trade with EU primarily as a result of the low level of competitiveness of the domestic agro-food sector. The importance of monitoring changes in terms of relative export competitiveness, led to development of revealed comparative advantage model (Liesner 1958, Balassa 1965) established in the second half of the twentieth century. Over the time the model evolved, including import and export as equally important factors of comparative advantage (Vollrath 1991, Leromain and Orefice 2013, Laursen 2015, etc.). Bearing in mind that the research so far dealt with the comparison of the comparative advantages of individual countries or group of countries in relation to their position to the World trade, authors provided new approach that will ensure monitoring of relative comparative trade relations between the two countries, especially comparing position of one country on specific market to its competitors on the same market. MORTA model will be used in order to recognize changes in relative comparative advantage in the process of trade liberalization between the EU and Serbia.

\section{Methodology}

Analysis of international trade based on the use of historical data (ex-post analysis), was first conducted by Liesner who tended to quantify comparative export advantage by comparing the observed exports of industrial products in the UK compared to their European competitors (Liesner, 1958). Although Liesner was the first scientist to quantify export comparative advantages, popularization of this model began in 1965 when the Balassa B. modified Liesner's model. Balassa for the first time used the term "revealed comparative advantage", which in practice often referred to as the Balassa index (Balassa, 1965). Critics of the concept of "revealed comparative advantage" revealed weaknesses in the theoretical and empirical sense (Leromain, Orefice, 2013, Yeats, 1985, Laursen, 2015, Dalum et al., 1998, Jambor, 2013, Benedictis, Tamberi, 2001).

Balassa index is a widely used model of identification of industry specialization in international trade and over the time became the basis of many future models (Bowen 1983, Lafay, 1992 (Sanidas and Shin 2010), Kanamori 1964, Vollrath 1991 (Vollrath 1991), Dalum et al 1998, Proudman and Redding 1998, Hoen and Osterhaven 2006, Yu et al.2009.g., Michaely 1962/67, CEPI 1983, Grubel and Lloyd 1971, (Ballance et al.1987), Laursen 2015, and others). Implementation of the revealed comparative advantage model in agriculture was applied by Vollrath 1989, Utkul and Seyman 2004, Fertõ and Bojnec 2007, Qineti et al. 2009, Bojnec and Fertõ 2012, Torok and Jambor 2012, Raičević et al., 2012, Ignjatijević et al. 2014, and others.

Taking into account previous researches, Market-Oriented Relative Trade Advantage

4 Certain number of products were not subject to SAA such as raw tobacco, raw and unrefined sugar and sunflower oil for human consumption which kept the same level of customs duties as before ITA implementation (Katić et al. 2008) 
(MORTA) is calculated as follows:

$$
\text { MORTA }=\text { MSXA - MSIA }
$$

Calculation of MORTA index represents the difference of market-oriented symmetric 5 relative comparative advantage in exports $(M S X A)$ :

$$
M S X A=\left(\frac{M X A_{a}^{i, m}-1}{M X A_{a}^{i, m}+1}\right)=\frac{\left(\left(\frac{X_{a}^{i, m}}{X_{n}^{i, m}}\right)-1\right)}{\left(\left(\frac{M_{a}^{w, m}}{M_{n}^{w, m}}\right)+1\right)}
$$

and market-oriented relative level of import penetration (MSIA):

$$
M S L A=\left(\frac{M L A_{a}^{i, m}-1}{M L A_{a}^{i, m}+1}\right)=\frac{\left(\left(\frac{M_{a}^{i, m}}{M_{n}^{i, m}}\right)-1\right)}{\left(\left(\frac{X_{a}^{m, w}}{X_{n}^{m, w}}\right)+1\right)}
$$

where $X$ represents export, $M$ represents import, $i$ represents country, $m$ represents observed market, $w$ represents group of countries that has trade relations with observed market $m, a$ represents observed product, $n$ represents all products.

If $M S X A>0$, relative comparative advantage in export is revealed in relation to all exporters of a observed market $m$. If $M S I A<0$, relative penetration level of the product $a$ from market $m$ in country $i$ is low. Comparing to MSXA and MSIA which gives values in the range -1 to $+1, M O R T A$ gives values ranging from -2 to +2 . In cases where the $M O R T A>0$, relative comparative trade advantage on observed market.

\section{Data}

Analysis of imports and exports data carried out on the base of the Standard International Trade Classification (SITC) rev. 4 (UNSTAT 2006), whereby the agro-food products, considered all the products presented in the framework of the SITC Section 0 - Food and live animals and Section 1 - Beverages and tobacco at the level to level five digits. Period 2004-2013 has been analyzed ensuring observation of trade movement in the period before and during the implementation of $\mathrm{SAA}^{6}$.

5 Symmetry is based on the concept of "revealed symmetrical comparative advantages" (Leromain, Orefice 2013)

6 Due to the fact that in the observed period EU enlargement occurred on three occasions (2004, 2007, and 2013), research will focus on all 28 EU Member States (EU28). Although the EU's enlargement occurred gradually, analysis performed take into account EU28 during observed period in order to avoid obtaining distorted results.

EP 2016 (63) 1 (247-260) 
The data used for research purposes are the official data of the Serbian Statistical Office (SSO) (available at: http://webrzs.stat.gov.rs/WebSite/public/ReportView.aspx) and official data of the Directorate General Eurostat (Eurostat) (available at: http://ec.europa.eu/eurostat/ web/international-trade/data/database) as the official statistical body of the EU, bearing in mind that the methodology of presenting information to each other are completely aligned expressing the value of FOB type in exports or CIF type in import (available at: http:// webrzs.stat.gov.rs/WebSite/Public/PageView.aspx?pKey=288 and Eurostat 2014). In the case of the EU, data relates to intra and extra trade.

Data published by the SSO and EUROSTAT are statistical data, and all values are expressed in current prices. Bearing in mind that the survey covers a period of 10 years, presenting the results of research in current prices will not provide realistic results of trade changes. In this respect, all values used in the study, are re-calculated into constant prices in order to realistic results that can be followed over time. Converting current to constant prices, in this paper unit value index (Unit Value Index) is applied, which is calculated using the following formula (IMF 2009):

$$
\text { Pcons }^{t}=\frac{\text { Pcur }^{t}}{P u^{0}}
$$

where Pcons ${ }^{t}$ shows export/import values in time $t$ expressed in constant prices, $P c u r^{t}$ shows export/import values in time $t$ expressed in current prices, $P u^{0}$ is index of unit value in the base year 0 .

In order to provide comprehensive analysis, standard statistical methods such as mode, median, arithmetic mean and trends are used in this research.

\section{Research results}

\section{Market oriented relative comparative advantage in export (MSXA) of Serbia on EU market}

In the export of Serbian agro-food products to the EU market, relative comparative advantage is revealed at the level of four SITC divisions, namely: division 04 with the median $M S X A$ value of 0.64 , division 05 with a median value of 0.62 , division 06 , with the median value of 0.84 and division 08 with median value of 0.04 (Table 1.). In divisions 04 , 05 and 06 relative comparative advantage in exports was observed throughout the period, with growth tendency in the export of cereals and cereal products, but declining trend of relative comparative advantage in the export of fruits and vegetables, as well as sugar and sugar confectioneries.

During the period, we can see the growth in the number of SITC products with revealed relative comparative advantage in exports whose share increases from 13.2\% in 2004 to $15.7 \%$ in 2013. On the other hand, there is an increasing trend of SITC products for which 
relative comparative advantage in export is not revealed with the lowest recorded share of $30.06 \%$ in 2005 and the highest share of $43.26 \%$ in 2013. Observed trends indicates that range of products that are being exported from Serbia to EU market increased but that further specialization in exports is necessary in order to improve the position of Serbia.

The importance of relative comparative advantage in the export of Serbia to the EU market, has been observed from the aspect of product life expectancy where positive MSXA value was observed in at least one year of the period (expressed in years). Overall, the average life expectancy of the product for which the relative comparative advantage in exports is revealed, was 5.15 years, while the share of products which had positive MSXA value at least in one year was $27.3 \%$. Looking at the average life expectancy by divisions, it can be seen that there are certain products with relative comparative advantage on the EU market even within the divisions which have negative MSXA value.

Table 1. Market oriented relative comparative advantage in export of agro-food products of Serbia on EU market by SITC division (2004-2013) - application of MSXA index

\begin{tabular}{|c|c|c|c|c|c|c|c|c|c|c|c|c|c|c|}
\hline & 00 & 01 & 02 & 03 & 04 & 05 & 06 & 07 & 08 & 09 & 11 & 12 & $\begin{array}{l}>0 \\
(\%)\end{array}$ & $\begin{array}{l}<0 \\
(\%)\end{array}$ \\
\hline '04 & .33 & -0.55 & -0.91 & .98 & 0.23 & 0.70 & 0.94 & -0.19 & 0.00 & 0.08 & -0.51 & -0.37 & 13.2 & 32.3 \\
\hline${ }^{\prime} 05$ & -0.42 & -0.52 & -0.97 & -0.99 & 0.59 & 0.66 & 0.92 & -0.10 & -0.27 & -0.06 & -0.49 & -0.72 & 14.9 & 30.1 \\
\hline '06 & -0.90 & -0.53 & -0.88 & -0.99 & 0.55 & 0.62 & 0.90 & -0.25 & -0.32 & -0.05 & -0.60 & -0.38 & 13.2 & 37.9 \\
\hline $\begin{array}{l} \\
\end{array}$ & -0.96 & -0.56 & -0.92 & 1.00 & 0.51 & 0.63 & 0.86 & -0.27 & 0.04 & -0.11 & -0.61 & -0.28 & 12.6 & 37.6 \\
\hline '08 & -0.93 & -0.66 & -0.93 & -0.99 & 0.40 & 0.59 & 0.85 & -0.35 & -0.02 & -0.14 & -0.46 & -0.15 & 12.6 & 39.6 \\
\hline '09 & -0.95 & \begin{tabular}{|l|}
-0.77 \\
\end{tabular} & -0.93 & -0.99 & 0.75 & 0.62 & 0.83 & -0.33 & $\begin{array}{l}0.08 \\
\end{array}$ & -0.08 & -0.24 & \begin{tabular}{|l|l|}
0.18 \\
\end{tabular} & 14.0 & 38.5 \\
\hline${ }^{\prime} 10$ & -0.96 & -0.78 & -0.94 & -0.99 & $\mathbf{0 . 8 0}$ & 0.59 & $\begin{array}{l}0.83 \\
\end{array}$ & -0.41 & 0.08 & -0.05 & -0.33 & \begin{tabular}{|l|l|}
0.17 \\
\end{tabular} & 13.2 & 45.2 \\
\hline${ }^{\prime} 11$ & -0.93 & -0.85 & -0.93 & -0.98 & $\begin{array}{l}0.80 \\
\end{array}$ & 0.62 & 0.80 & -0.51 & $\begin{array}{l}0.19 \\
\end{array}$ & -0.10 & -0.18 & \begin{tabular}{|l|l|}
0.13 \\
\end{tabular} & 14.9 & 46.1 \\
\hline${ }^{\prime} 12$ & -0.92 & -0.86 & -0.82 & -0.97 & $\begin{array}{l}0.84 \\
\end{array}$ & 0.54 & 0.82 & -0.55 & $\begin{array}{l}0.28 \\
\end{array}$ & -0.02 & -0.02 & \begin{tabular}{|l|l|}
0.24 \\
\end{tabular} & 16.0 & 45.2 \\
\hline '13 & -0.95 & -0.90 & -0.80 & -0.98 & 0.68 & 0.48 & 0.77 & -0.61 & 0.03 & 0.05 & -0.23 & 0.02 & 15.7 & 43.3 \\
\hline$M e$ & -0.93 & -0.72 & -0.92 & -0.99 & 0 & 2 & 0.84 & -0 & 0.04 & -0.06 & -0.39 & -0.06 & & \\
\hline Mo & -0.83 & -0.70 & -0.90 & -0.99 & 0.62 & 0.61 & 0.85 & -0.36 & 0.01 & -0.05 & -0.37 & -0.12 & & \\
\hline$\sigma$ & 0.08 & 0.05 & 0.02 & 0.00 & 0.06 & 0.02 & 0.02 & 0.05 & 0.06 & 0.02 & 0.06 & 0.10 & & \\
\hline \multicolumn{13}{|c|}{$\begin{array}{l}\text { Average life expectancy of the product with the revealed relative comparative } \\
\text { advantage in exports }(M S X A>0)\end{array}$} & $\sum$ & $\begin{array}{c}\text { MSXA>0 } \\
(\%)\end{array}$ \\
\hline & 2.0 & 5.7 & 2.0 & - & 4.4 & 6.0 & 4.6 & 4.8 & 4.0 & 5.3 & 5.7 & 6.2 & 5.15 & 27.2 \\
\hline
\end{tabular}

Source: Author's calculation based on EUROSTAT and SSO data

Serbia's export to the EU market, is almost completely dominated by the export of primary agricultural products. Although Serbia has a relative comparative advantage in exporting to the EU market under four divisions, bearers of good results are based on a small number of export products, of which the most important are presented individually (Table 2.). Within the division 04, the most important export product was commercial maize where the MSXA values were at a high level, especially in the second half of the observed period that arise, as a direct consequence of the application of Interim Trade Agreement (ITA) (Official Gazette 83/2008) by new Member states. Namely, after EU accession in 2007, Romania started to become the most important trade partner of Serbia in the EU when it comes to agro-food 
sector. The slightly lower MSXA value of SITC product 04490 in 2013, was a consequence of the reduced export value due to drought and export bans set by Serbian government in 2013. In fruit export, the relative market position of Serbia in the EU market recorded very good results especially when it comes to exports of frozen raspberries and other berries (05832), which is the most important export product of Serbia. Its relative comparative advantage in exports, Serbia maintained at the maximum level throughout the period with almost maximum $M S X A$ values. In addition to these, a significant exports share was realized in sugar export (06129) thanks to the preferential export regime of EU which is limited to 180,000 tons per annum (Official Gazette 83/2008). Although the relative comparative advantage in the export of Serbia in the EU market is at high level, mild downward trend of $M S X A$ values was observed. Having in mind that preferential regime for sugar export is limited by maximum quantity, increasing of quotas would definitely contribute to further strengthening of relative comparative advantage of Serbia in the EU market.

Table 2. Market oriented relative comparative advantage in export of most significant agro-food products of Serbia on EU market (2004-2013) - application of MSXA index

\begin{tabular}{|c|c|c|r|r|r|r|r|r|r|r|r|c|}
\hline SITC & $\mathbf{9}$ & $\mathbf{2 0 0 4}$ & $\mathbf{2 0 0 5}$ & $\mathbf{2 0 0 6}$ & $\mathbf{2 0 0 7}$ & $\mathbf{2 0 0 8}$ & $\mathbf{2 0 0 9}$ & $\mathbf{2 0 1 0}$ & $\mathbf{2 0 1 1}$ & $\mathbf{2 0 1 2}$ & $\mathbf{2 0 1 3}$ & Me \\
\hline 05832 & 12.4 & 1.00 & 1.00 & 1.00 & 0.99 & 0.99 & 0.99 & 0.99 & 0.99 & 0.99 & 0.99 & 0.99 \\
\hline 05839 & 3.8 & 0.97 & 0.97 & 0.96 & 0.97 & 0.96 & 0.96 & 0.97 & 0.97 & 0.96 & 0.95 & 0.96 \\
\hline 08152 & 1.0 & 0.97 & 0.95 & 0.95 & 0.97 & 0.94 & 0.96 & 0.97 & 0.96 & 0.94 & 0.93 & 0.95 \\
\hline 06129 & 11.8 & 0.98 & 0.97 & 0.97 & 0.96 & 0.95 & 0.94 & 0.94 & 0.93 & 0.93 & 0.92 & 0.95 \\
\hline 04490 & 11.5 & 0.77 & 0.94 & 0.93 & 0.70 & 0.84 & 0.97 & 0.97 & 0.96 & 0.97 & 0.79 & 0.93 \\
\hline 05995 & 1.2 & 0.88 & 0.91 & 0.90 & 0.86 & 0.81 & 0.77 & 0.89 & 0.91 & 0.87 & 0.86 & 0.87 \\
\hline 04410 & 1.2 & 0.66 & 0.57 & 0.67 & 0.71 & 0.85 & 0.85 & 0.81 & 0.76 & 0.82 & 0.87 & 0.78 \\
\hline 05458 & 0.6 & 0.92 & 0.90 & 0.88 & 0.83 & 0.73 & 0.82 & 0.72 & 0.72 & 0.23 & 0.32 & 0.78 \\
\hline 05469 & 1.2 & 0.80 & 0.75 & 0.70 & 0.72 & 0.61 & 0.68 & 0.68 & 0.68 & 0.69 & 0.66 & 0.68 \\
\hline 04120 & 2.9 & 0.17 & 0.53 & -0.79 & 0.73 & -0.86 & -0.36 & 0.79 & 0.70 & 0.73 & 0.89 & 0.62 \\
\hline 12120 & 1.8 & 0.17 & -0.30 & 0.35 & 0.53 & 0.55 & 0.72 & 0.69 & 0.66 & 0.72 & 0.57 & 0.56 \\
\hline
\end{tabular}

Source: Author's calculation based on EUROSTAT and SSO data

\section{Market-oriented relative level of import penetration (MSIA) of EU on Serbian market}

In import of agro-food products from EU to Serbia, relatively low level of penetration was observed in most of the divisions with negative MSIA median values. In SITC divisions 06, 07, 09 and 12 MSIA median value is greater than 0 , which indicates that the relative level of EU's penetration is high (Table 3.). In divisions 01, 02, 03, 04, 05 and 11 a relatively low level of penetration can be seen in all observed years. However, in all divisions, there is a noticeable increase in the $M S I A$ values indicating an upward trend in the relative position of the EU in Serbia. In division 00, the MSIA value is negative in all observed years, except in the last two observed years with constant growth trend of the index value indicating a higher relative level of penetration of the product of the observed division's products on the Serbian market. On the other hand, in the division 08 MSIA values are negative in all years except in 2006 and 2013, which did not significantly affect the overall relative level 
of penetration in the reporting period, with the median value of -0.03 . Highest MSIA value is recorded in the division 09 with a value of 0.27 , while the tendency of lowering the relative level of penetration of observed products groups is visible. Division 12 products in all observed years recorded a relatively high level of import penetration, but with visible tendency of re-growth of the index value in the second half of the period.

Table 3. Market oriented relative import penetration of agro-food products in Serbia from EU by SITC divisions (2004-2013) - application of MSIA index

\begin{tabular}{|c|c|c|c|c|c|c|c|c|c|c|c|c|c|c|}
\hline & 00 & 01 & 02 & 03 & 04 & 05 & 06 & 07 & 08 & 09 & 11 & 12 & $\begin{array}{l}>0 \\
(\%)\end{array}$ & \begin{tabular}{|l}
$<0$ \\
$(\%)$
\end{tabular} \\
\hline${ }^{\prime} 04$ & \begin{tabular}{|l|}
-0.48 \\
\end{tabular} & \begin{tabular}{|l|}
-0.59 \\
\end{tabular} & -0.56 & -0.24 & -0.05 & \begin{tabular}{|l|l|}
-0.16 \\
\end{tabular} & \begin{tabular}{|l|}
0.17 \\
\end{tabular} & 0.18 & \begin{tabular}{|l|l}
0.00 \\
\end{tabular} & 0.47 & \begin{tabular}{|c|}
-0.52 \\
\end{tabular} & 0.52 & 24.7 & 57.3 \\
\hline '05 & \begin{tabular}{|l|l|}
-0.13 \\
\end{tabular} & \begin{tabular}{|l|}
-0.59 \\
\end{tabular} & $\begin{array}{l}-0.66 \\
\end{array}$ & \begin{tabular}{|c|}
-0.17 \\
\end{tabular} & \begin{tabular}{|c|c|}
-0.09 \\
\end{tabular} & -0.16 & 0.31 & 0.14 & 0.00 & 0.50 & -0.57 & 0.47 & 25.6 & 52.8 \\
\hline${ }^{\prime} 06$ & \begin{tabular}{|l|}
-0.35 \\
\end{tabular} & \begin{tabular}{|l|}
-0.64 \\
\end{tabular} & $\begin{array}{l}-0.67 \\
\end{array}$ & \begin{tabular}{|c|}
-0.24 \\
\end{tabular} & \begin{tabular}{|l|}
-0.10 \\
\end{tabular} & -0.13 & \begin{tabular}{|l|l|}
0.13 \\
\end{tabular} & 0.01 & \begin{tabular}{|l|}
0.14 \\
\end{tabular} & 0.34 & \begin{tabular}{|c|}
-0.52 \\
\end{tabular} & 0.48 & 24.7 & 54.8 \\
\hline '07 & \begin{tabular}{|l|}
-0.28 \\
\end{tabular} & \begin{tabular}{|l|}
-0.72 \\
\end{tabular} & $\begin{array}{l}-0.64 \\
\end{array}$ & \begin{tabular}{|c|}
-0.31 \\
\end{tabular} & \begin{tabular}{|l|l|}
-0.27 \\
\end{tabular} & \begin{tabular}{|l}
-0.19 \\
\end{tabular} & \begin{tabular}{|l|l|}
-0.05 \\
\end{tabular} & 0.16 & -0.05 & 0.24 & -0.55 & 0.14 & 21.9 & 59.0 \\
\hline '08 & \begin{tabular}{|l|}
-0.34 \\
\end{tabular} & \begin{tabular}{|l|}
-0.61 \\
\end{tabular} & $\begin{array}{l}-0.53 \\
\end{array}$ & -0.28 & \begin{tabular}{|l|l|}
-0.29 \\
\end{tabular} & -0.15 & \begin{tabular}{|l|}
-0.11 \\
\end{tabular} & 0.17 & -0.13 & 0.26 & -0.48 & 0.18 & 21.9 & 58.4 \\
\hline '09 & \begin{tabular}{|l|}
-0.34 \\
\end{tabular} & \begin{tabular}{|l|}
-0.58 \\
\end{tabular} & $\begin{array}{l}-0.72 \\
\end{array}$ & -0.35 & \begin{tabular}{|l|}
-0.51 \\
\end{tabular} & -0.20 & \begin{tabular}{|l|}
-0.14 \\
\end{tabular} & -0.19 & -0.26 & 0.07 & -0.58 & 0.04 & 18.5 & 63.2 \\
\hline${ }^{\prime} 10$ & \begin{tabular}{|l|l|}
-0.64 \\
\end{tabular} & \begin{tabular}{|l|}
-0.60 \\
\end{tabular} & $\begin{array}{l}-0.51 \\
\end{array}$ & \begin{tabular}{|c|}
-0.38 \\
\end{tabular} & \begin{tabular}{|l|}
-0.51 \\
\end{tabular} & -0.19 & \begin{tabular}{|c|c|}
-0.13 \\
\end{tabular} & $\begin{array}{l}-0.02 \\
\end{array}$ & -0.15 & 0.15 & -0.63 & 0.07 & 17.7 & 66.0 \\
\hline '11 & \begin{tabular}{|l|l|}
-0.28 \\
\end{tabular} & -0.55 & $\begin{array}{l}-0.41 \\
\end{array}$ & -0.23 & -0.25 & -0.12 & \begin{tabular}{|l|l|}
-0.03 \\
\end{tabular} & 0.06 & \begin{tabular}{|c|}
-0.03 \\
\end{tabular} & 0.28 & -0.46 & 0.16 & 21.9 & 62.6 \\
\hline '12 & 0.03 & -0.40 & -0.42 & \begin{tabular}{|c|c|}
-0.17 \\
\end{tabular} & -0.21 & \begin{tabular}{|l|l|}
-0.11 \\
\end{tabular} & \begin{tabular}{|l|}
0.04 \\
\end{tabular} & 0.06 & -0.04 & 0.28 & -0.46 & 0.21 & 23.6 & 61.5 \\
\hline '13 & 0.09 & \begin{tabular}{|l|l|} 
\\
\end{tabular} & -0.47 & -0.22 & \begin{tabular}{|c|c|}
-0.20 \\
\end{tabular} & -0.13 & \begin{tabular}{|l|l|}
0.13 \\
\end{tabular} & 0.07 & 0.04 & 0.25 & -0.49 & 0.29 & 24.2 & 63.8 \\
\hline$M e$ & -0.31 & -0.59 & -0.54 & -0.24 & -0.23 & -0.15 & \begin{tabular}{|l|}
0.01 \\
\end{tabular} & 0.07 & -0.03 & 0.27 & \begin{tabular}{|c|c|}
-0.52 \\
\end{tabular} & 0.20 & & \\
\hline Mo & -0.27 & -0.56 & -0.56 & -0.26 & -0.25 & -0.15 & \begin{tabular}{|l|}
0.03 \\
\end{tabular} & 0.06 & -0.05 & 0.28 & -0.53 & 0.26 & & \\
\hline$\sigma$ & 0.07 & 0.03 & 0.04 & \begin{tabular}{|l|}
0.02 \\
\end{tabular} & 0.05 & 0.01 & \begin{tabular}{|l|l}
0.05 \\
\end{tabular} & 0.04 & \begin{tabular}{|l|}
0.04 \\
\end{tabular} & 0.04 & 0.02 & 0.06 & & \\
\hline \multicolumn{13}{|c|}{ Average life expectancy of products with relatively high import penetration (MSIA>0) } & $\sum$ & $\begin{array}{c}\text { MSIA } \\
>0 \\
(\%)\end{array}$ \\
\hline & 5.6 & 4.0 & 2.9 & 7.6 & 4.4 & 5.1 & 5.3 & 5.6 & 4.3 & 7.1 & 2.0 & 6.1 & 5.23 & 42.9 \\
\hline
\end{tabular}

Source: Author's calculation based on EUROSTAT and SSO data

In the structure of the observed SITC products, more than half are products in which the $M S I A$ value is less than 0 indicating a relatively low level of import penetration of EU products with a tendency of increasing number of such products. In 2010, 2/3 of the imported products from the EU recorded a negative MSIA value. On the other hand, growing share of products with high level of import penetration in Serbia is observed in the second half of the period. The largest share of products with relatively high import penetration was recorded in the first three observed years.

Overall, the average life expectancy of the products with positive MSIA values is 5.23 years while the total share of products with at least one year with positive MSIA value reached 42.98\%. Like in the export, it can be noted that there are products within the divisions with negative $M S I A$ values that had relatively high level of import penetration of the EU to the Serbian market.

While Serbia has a relatively high comparative advantage in export to EU, on the other side it can be recognized that EU recorded relatively low level of import penetration. By analyzing most important import products from EU, we can see presence of products with 
negative MSIA values, which indicates a relatively low level of penetration in the market of Serbia (Table 4). However, generally speaking, there is a growth tendency of MSIA values during the period in most import products from EU.

Table 4. Market oriented relative import penetration of most significant agro-food products in Serbia from EU (2004-2013) - application of MSIA index

\begin{tabular}{|c|c|c|c|c|c|c|c|c|c|c|c|c|}
\hline SITC & $\mathbf{\%}$ & $\mathbf{2 0 0 4}$ & $\mathbf{2 0 0 5}$ & $\mathbf{2 0 0 6}$ & $\mathbf{2 0 0 7}$ & $\mathbf{2 0 0 8}$ & $\mathbf{2 0 0 9}$ & $\mathbf{2 0 1 0}$ & $\mathbf{2 0 1 1}$ & $\mathbf{2 0 1 2}$ & $\mathbf{2 0 1 3}$ & Me \\
\hline 06196 & 1.3 & 0.91 & 0.92 & 0.95 & 0.96 & 0.96 & 0.96 & 0.92 & 0.94 & 0.95 & 0.96 & 0.95 \\
\hline 09860 & 1.3 & 0.76 & 0.78 & 0.74 & 0.63 & 0.64 & 0.66 & 0.72 & 0.71 & 0.71 & 0.79 & 0.72 \\
\hline 05771 & 3.4 & 0.42 & 0.68 & 0.68 & 0.67 & 0.70 & 0.71 & 0.69 & 0.75 & 0.67 & 0.66 & 0.68 \\
\hline 12120 & 2.4 & 0.49 & 0.69 & 0.68 & 0.40 & 0.53 & -0.52 & 0.53 & 0.83 & 0.81 & 0.81 & 0.60 \\
\hline 05712 & 2.3 & 0.38 & 0.24 & 0.54 & 0.57 & 0.56 & 0.54 & 0.57 & 0.57 & 0.57 & 0.49 & 0.55 \\
\hline 09899 & 10.7 & 0.67 & 0.67 & 0.46 & 0.37 & 0.42 & 0.18 & 0.21 & 0.38 & 0.41 & 0.34 & 0.39 \\
\hline 07330 & 3.5 & 0.54 & 0.26 & 0.21 & 0.24 & 0.25 & 0.18 & 0.22 & 0.22 & 0.17 & 0.16 & 0.22 \\
\hline 07131 & 1.9 & 0.19 & 0.00 & -0.04 & 0.14 & 0.18 & 0.16 & 0.24 & 0.27 & 0.23 & 0.19 & 0.18 \\
\hline 12220 & 5.6 & 0.54 & 0.43 & 0.48 & 0.13 & 0.16 & 0.20 & 0.09 & -0.17 & -0.38 & -0.32 & 0.15 \\
\hline 01222 & 2.0 & -0.13 & -0.14 & -0.49 & -0.41 & -0.09 & -0.04 & -0.28 & -0.02 & 0.30 & 0.35 & -0.11 \\
\hline 04849 & 1.3 & 0.17 & -0.02 & -0.33 & -0.61 & -0.55 & -0.83 & -0.73 & -0.44 & -0.31 & -0.32 & -0.38 \\
\hline 06229 & 1.3 & -0.19 & -0.34 & -0.44 & -0.84 & -0.66 & -0.27 & -0.50 & -0.36 & -0.38 & -0.42 & -0.40 \\
\hline 11102 & 1.3 & -0.42 & -0.44 & -0.47 & -0.43 & -0.25 & -0.47 & -0.41 & -0.44 & -0.32 & -0.26 & -0.43 \\
\hline
\end{tabular}

Source: Author's calculation based on EUROSTAT and SSO data

\section{Market oriented relative comparative trade advantage (MORTA) in agro-food trade between Serbia and EU}

High $M S X A$ values, as well as the relatively low MSIA value in agro-food trade between Serbia and EU determine MORTA value which is an indicator of the relative level of comparative trade advantage. As one can see, in trade between Serbia and EU, relative comparative trade advantage lays down on Serbia within the divisions 04, 05, 06, 08 and 11 which are the divisions in which Serbia has a significant export results (Table 5.). On the other hand, negative MORTA values indicate that relative comparative trade advantage is not revealed.

The share of products with revealed comparative trade advantage of Serbia in trade with the EU, fluctuate over time from the lowest recorded value of $19.38 \%$ in 2004 , up to a maximum recorded value of $26.69 \%$ in 2010 . Overall, there is a noticeable increase in the number of products where relative comparative trade advantage is revealed on the side of Serbia in trade with EU. Also, it can be noticed that the share of products with positive MORTA values is greater than the share of products with positive MSXA values which indicates that Serbia performed better results in mutual trade as a result of lower level of import penetration from EU.

The average life expectancy of products with revealed relative comparative trade advantage is 4.75 years in the observed ten-year period. Below average life expectancy is revealed only in division 06 which amounts 3.91 years. The longest life expectancy of 7 years was noticed in SITC division 00 where negative MORTA values are present in all observed 
years except in 2004. Although relative comparative trade advantage at the level of divisions is not revealed, it is evident that there are products within divisions where relative comparative trade advantage is revealed.

Table 5. Market oriented relative comparative trade advantages of Serbia in trade of agrofood products between Serbia and EU by SITC divisions (2004-2013) - application of MORTA index

\begin{tabular}{|c|c|c|c|c|c|c|c|c|c|c|c|c|c|c|}
\hline & 00 & 01 & 02 & 03 & 04 & 05 & 06 & 07 & 08 & 09 & 11 & 12 & $\begin{array}{l}>0 \\
(\%)\end{array}$ & $\begin{array}{ll}<0 \\
(\%)\end{array}$ \\
\hline '04 & \begin{tabular}{|l|l|}
0.15 \\
\end{tabular} & \begin{tabular}{|l|}
0.04 \\
\end{tabular} & -0.35 & 0.74 & 28 & 0.86 & 0.76 & -0.37 & 0.00 & \begin{tabular}{|l}
-0.39 \\
\end{tabular} & \begin{tabular}{|l|}
0.01 \\
\end{tabular} & \begin{tabular}{|l}
-0.89 \\
\end{tabular} & 19.4 & 64.3 \\
\hline '05 & -0.29 & 0.07 & -0.31 & -0.83 & 0.69 & 0.82 & 0.61 & -0.23 & -0.28 & -0.56 & 0.08 & -1.20 & 20.2 & 61.2 \\
\hline '06 & -0.55 & 0.11 & -0.20 & -0.75 & 0.64 & 0.74 & 0.76 & -0.26 & -0.46 & \begin{tabular}{|l|}
-0.39 \\
\end{tabular} & \begin{tabular}{|l|}
-0.08 \\
\end{tabular} & \begin{tabular}{|l}
-0.86 \\
\end{tabular} & 21.1 & 61.8 \\
\hline '07 & -0.68 & 0.16 & -0.28 & -0.69 & 0.78 & 0.83 & 0.92 & -0.43 & 0.10 & -0.34 & -0.05 & -0.43 & 21.1 & 62.6 \\
\hline '08 & -0.59 & -0.05 & -0.40 & -0.71 & 0.68 & 0.74 & 0.95 & -0.52 & 0.11 & -0.40 & \begin{tabular}{|l|}
0.02 \\
\end{tabular} & \begin{tabular}{|l}
-0.33 \\
\end{tabular} & 22.2 & 61.0 \\
\hline '09 & -0.61 & -0.19 & -0.21 & -0.64 & 1.26 & 0.82 & 0.97 & -0.15 & 0.34 & -0.15 & 0.35 & 0.14 & 24.4 & 60.1 \\
\hline ' 10 & -0.32 & -0.18 & -0.42 & -0.60 & 1.31 & 0.78 & 0.96 & -0.38 & 0.24 & -0.20 & 0. & \begin{tabular}{|l}
0.10 \\
\end{tabular} & 26.7 & 61.0 \\
\hline '11 & -0.65 & -0.29 & -0.53 & -0.75 & 1.05 & 0.74 & 0.83 & -0.56 & 0.22 & -0.38 & 0.28 & -0.03 & 26.1 & 62.1 \\
\hline '12 & -0.95 & -0.47 & -0.41 & -0.80 & 1.05 & 0.65 & 0.77 & -0.61 & 0.32 & -0.30 & 0. & \begin{tabular}{|l|l|}
0.02 \\
\end{tabular} & 24.7 & 63.5 \\
\hline '13 & -1.04 & -0.54 & -0.33 & -0.75 & 0.89 & 0.61 & 0.63 & -0.68 & -0.01 & -0.20 & 0.26 & -0.26 & 24.7 & 66.0 \\
\hline Me & -0.60 & -0.11 & -0.34 & -0.74 & 0.83 & 0.76 & 0.80 & -0.41 & 0.10 & -0.36 & 0.17 & -0.30 & & \\
\hline Mo & -0.55 & -0.13 & -0.34 & -0.73 & 0.86 & 0.76 & 0.82 & -0.42 & 0.06 & -0.33 & 0.16 & -0.37 & & \\
\hline$\sigma$ & 0.11 & 0.08 & 0.03 & 0.02 & 0.10 & 0.03 & 0.04 & 0.06 & 0.08 & \begin{tabular}{|l|l}
0.04 \\
\end{tabular} & 0.06 & 0.15 & & \\
\hline \multicolumn{13}{|c|}{$\begin{array}{l}\text { Average life expectancy of products with revealed comparative trade advantage } \\
(M O R T A>0)\end{array}$} & $\sum$ & $\begin{array}{c}\text { MORTA }>0 \\
(\%)\end{array}$ \\
\hline & 7.0 & 3.5 & 1.9 & 2.0 & 6.0 & 5.9 & 3.9 & 2.9 & 5.2 & 4.4 & 5.3 & 3.0 & 4.75 & 48.6 \\
\hline
\end{tabular}

Source: Author's calculation based on EUROSTAT and SSO data

Analyzing selected agro-food products, it can be seen that Serbia has achieved a relative comparative trade advantage for products where export results are strong on the EU market (Table 6.). Relatively low median MORTA value in trade of SITC 05832, 04410 and 05995 indicates that their relative significance in import to Serbia from EU is also present. On the other hand, products with a relatively high level of penetration in Serbia, consequently contributes that EU's relative comparative trade advantages is revealed in trade with Serbia. In the case of SITC product 09860, despite the high MSIA value, relative comparative trade advantage is revealed, bearing in mind that the relative importance of Serbia's export to the EU market is higher. In the case of SITC 01222 comparative trade advantage is not revealed despite the fact that in most of the period, the MSIA value is negative, which is a consequence of low relative level of export penetration of Serbia. 
Table 6. Market oriented revealed comparative trade advantage of most significant agro-food products in trade between Serbia and EU (2004-2013) - application of MORTA index

\begin{tabular}{|c|c|c|c|c|c|c|c|c|c|c|c|}
\hline SITC & 2004 & 2005 & 2006 & 2007 & 2008 & 2009 & 2010 & 2011 & 2012 & 2013 & $\overline{M e}$ \\
\hline 06196 & -1.91 & -1.92 & -1.95 & -1.96 & -1.96 & -1.96 & -1.91 & -1.74 & -1.89 & -1.96 & -1.94 \\
\hline 09860 & 0.08 & 0.00 & 0.03 & 0.20 & 0.16 & 0.17 & 0.13 & 0.10 & 0.09 & $\begin{array}{l}-0.59 \\
\end{array}$ & 0.10 \\
\hline 05711 & -1.42 & -1.68 & -1.67 & -1.67 & -1.69 & -1.69 & -1.69 & -1.75 & -1.64 & -1.65 & -1.67 \\
\hline 12120 & -0.31 & $\begin{array}{l}-0.99 \\
\end{array}$ & -0.32 & 0.13 & 0.02 & 1.24 & 0.16 & -0.17 & -0.08 & -0.24 & -0.12 \\
\hline 05712 & -1.38 & -1.23 & -1.52 & -1.57 & -1.56 & -1.49 & -1.56 & -1.51 & -1.51 & -1.44 & -1.51 \\
\hline 09899 & -0.45 & -0.58 & -0.41 & -0.44 & -0.48 & -0.22 & -0.30 & -0.43 & -0.30 & -0.03 & -0.42 \\
\hline 07330 & -0.65 & -0.20 & -0.17 & -0.46 & -0.57 & -0.47 & -0.57 & -0.58 & -0.55 & -0.67 & -0.56 \\
\hline 07131 & -1.19 & -1.00 & -0.96 & -1.14 & -1.06 & -1.14 & -1.12 & -1.23 & -1.10 & -1.16 & -1.13 \\
\hline 12220 & -1.54 & -1.42 & -1.45 & -1.13 & -1.16 & -0.77 & -0.88 & -0.28 & -0.43 & -0.48 & -1.00 \\
\hline 01222 & -0.87 & -0.86 & -0.51 & -0.59 & -0.91 & -0.96 & -0.72 & -0.98 & -1.30 & -1.35 & -0.89 \\
\hline 04849 & 0.08 & 0.17 & 0.01 & 0.26 & 0.29 & 0.43 & 0.45 & 0.18 & 0.09 & -0.08 & 0.18 \\
\hline 06229 & -0.26 & 0.13 & 0.13 & 0.63 & 0.32 & -0.02 & 0.13 & -0.01 & 0.03 & -0.14 & 0.08 \\
\hline 11102 & -0.41 & -0.23 & -0.25 & -0.07 & -0.28 & 0.25 & 0.31 & 0.48 & 0.63 & 0.51 & 0.09 \\
\hline 05832 & 0.47 & 0.42 & 0.33 & 0.30 & 0.32 & 0.33 & 0.32 & 0.37 & 0.22 & 0.24 & 0.33 \\
\hline 05839 & 1.15 & 1.40 & 1.33 & 1.21 & 0.98 & 0.74 & 1.13 & 0.80 & 0.66 & 0.60 & 1.06 \\
\hline 08152 & 1.83 & 1.95 & 1.91 & 1.87 & 1.89 & 1.87 & 1.93 & 1.93 & 1.75 & 1.84 & 1.88 \\
\hline 06129 & 0.88 & 0.65 & 1.15 & 1.84 & 1.88 & 1.93 & 1.93 & 1.78 & 1.93 & 1.91 & 1.86 \\
\hline 04490 & 1.28 & 1.92 & 1.91 & 1.69 & 1.82 & 1.94 & 1.95 & 1.95 & 1.81 & 1.61 & 1.87 \\
\hline 05995 & 0.49 & 0.54 & 0.59 & 0.76 & 0.60 & 0.65 & 0.96 & 0.85 & 0.87 & 0.60 & 0.63 \\
\hline 04410 & 0.43 & 0.53 & 0.42 & 0.69 & 0.49 & 0.30 & 1.03 & 0.22 & 0.13 & 0.18 & 0.43 \\
\hline 05458 & 1.49 & 1.72 & 1.75 & 1.82 & 1.70 & 1.78 & 1.67 & 1.71 & 1.19 & 1.29 & 1.71 \\
\hline 05469 & 1.49 & 1.43 & 1.24 & 1.37 & 1.18 & 1.50 & 1.42 & 1.28 & 1.16 & 1.09 & 1.33 \\
\hline 04120 & 1.15 & 1.53 & 0.21 & 1.72 & 0.13 & 0.64 & 1.78 & 1.66 & 1.66 & 1.86 & 1.59 \\
\hline
\end{tabular}

Source: Author's calculation based on EUROSTAT and SSO data

\section{Conclusion}

Trade liberalization between Serbia and the EU through SAA, undoubtedly contributed to the enhancement of mutual trade relations in trade agro-food products, which is manifested, above all, by trade value growth. Considering all SITC agro-food products it can be seen that during the ITA implementation, total number of traded products increased with a simultaneous increase in the share of products in which relative comparative trade advantage is revealed with significantly wider range of products imported from the EU, in relation to the range of products which are exported to EU market. However, the wide possibilities of liberalization of mutual trade relations have not been exploited fully, which leaves room for further improvement of trade relations.

Although Serbia managed to increase share of products with revealed relative comparative advantage of export to EU during ITA implementation, in the same period share of products with relatively high penetration from EU market also increased. Overall, Serbia managed to increase share of products with revealed relative comparative trade advantage in trade with the EU in relation to the period before the ITA implementation which is a clear indication 
that the liberalization of trade relations with the EU has not led to distortion of Serbian comparative advantages. On the contrary, presented results of the most important traded products showed that both Serbia and the EU are improving their trade relations primarily on complementary products. However, there are products where relative comparative advantage is weakening over time on both sides, which requires observation and possible corrections of agrarian policy makers, especially in Serbia, bearing in mind the importance of the EU market.

MORTA concept presented in this paper can be considered as an appropriate alternative model of revealed comparative advantage which can be used on any country and on any product industry.

\section{Literature}

1. Ballance, R.H., Forstner H., Murray T. (1987): Consistency tests of alternative measures of comparative advantage, The Review of Economics and Statistics, Vol. 69, No.1, pp.157-161, MIT Press, Cambridge, MA 02142 USA (available at: http://www.jstor.org/ stable/1937915)

2. Balassa, B. (1965): Trade Liberalization and "Revealed" Comparative Advantage, The Manchester School, Vol.3, issue 2, pp.99-123, John Wiley \& Sons Ltd, PO22 9NQ UK (available at: http://onlinelibrary.wiley.com).

3. Benedictis L.D., Tamberi M. (2001): A note on the Balassa Index of Revealed Comparative Advantage, Social Science Electronic Publishing Inc., NY, USA (available at: http://papers.ssrn.com/sol3/papers.cfm?abstract id=289602).

4. Bojnec, Š., Fertő, I. (2012): Complementarities of trade advantage and trade competitiveness measures, Applied economics Vol. 2, No. 4, pp. 399-408., Routledge Taylor \& Francis Group Ltd, Oxford, UK (available at: http://onesearch.lancs.ac.uk).

5. Bowen, Harry P.(1983): On the Theoretical Interpretation of Indices of Trade Intensity and Revealed Comparative Advantage, Weltwirtschaftliches Archiv, Vol. 119, No. 3, pp. 464-472, Springer, NY, USA (available at: http://www.jstor.org/stable/40439150).

6. Dalum, B., Laursen, K., Villumsen, G. (1998): Structural change in OECD export specialisation patterns: de-specialisation and 'stickiness', International Review of Applied Economics, Vol. 12, No. 3, pp. 423-443, Routledge Taylor \& Francis Group Ltd, Oxford, UK (available at: http://www.tandfonline.com/).

7. Eurostat Databease on International Trade, European Commission (available at: http:// ec.europa.eu/eurostat/web/international-trade/data/database), database accessed during March-July 2015

8. Export and Import Price Index Manual - Theory and practice, International Monetary fund, 2009 Washington D.C.

9. Fertö, I., Bojnec Š. (2009): Comparative advantages in agro-food trade of Central European and Balkans' countries with the European Union, Food policy, Vol. 34, No. 5, pp. 417-425, Elsevier B.V., Philadelphia, USA (available at: https://www.researchgate.net). 
10. Grubel, H.G., Lloyd, P.J. (1971): The Empirical Measurement of Intraindustry Trade, The Economic Record, Vol. 47, pp. 494-517, The Economic Society of Australia, Willoughby, Australia (available at: http://onlinelibrary.wiley.com).

11. Ignjatijević, S., Čavlin, M., Đorđević, D. (2014): Measurement of comparative advantages of processed food sector of Serbia in the increasing the export, Economics of Agriculture, Vol. 3, pp. 677-694, Institute of Agricultural Economics, Belgrade, Serbia (available at: http://www.iep.bg.ac.rs/).

12. Jambor A. (2013): Comparative advantages and specialization of the Visegrad countries agri-food trade, Acta Oeconomica et Informatica, Vol. 16, No. 1, pp. 22-34, Nitra, Slovakia (available at: http://ageconsearch.umn.edu).

13. Katić, B., Popović, V., Milanović, R.M. (2008): Influence of stabilization and association agreement to the agriculture of the Republic of Serbia, Economics of Agriculture, Vol. 4, pp. 339-354, Institute of Agricultural Economics, Belgrade, Serbia (available at: http:// www.iep.bg.ac.rs/).

14. Leromain, E., Orefice, G. (2013): New Revealed Comparative Advantage Index: dataset and empirical distribution, CEPII, No. 20, Paris, France (available at: http:/www.cepii. fr).

15. Laursen, K (2015): Revealed comparative advantage and the alternatives as measures of international specialization, Eurasian Business Review, No. 5, pp. 99-115, Springer, NY, USA (available at: http://www.druid.dk).

16. Liesner, H.H. (1958): The European Common Market and British industry, The Economic Journal, Vol. 68, pp. 302-316, Royal Economic Society, London, UK (available at: https://www.researchgate.net/).

17. Michaely, M. (1962): Concentration in international trade, North-Holland Publishing Company, Amsterdam, Netherland (available at: http://www.abebooks.com/).

18. Raičević V., Ignjatijević S., Matijašević J.(2012): Economic and legal determinants of export competitiveness of the food industry of Serbia, Industrija Vol.40, No.1, pp.201-226, Economic Institute, Belgrade, Serbia (available at: http://www.ecinst.org.rs/industrija).

19. Database of international trade, Serbian Statistical Office, (available at: http://webrzs. stat.gov.rs/WebSite/public/ReportView.aspx), database accessed during May-September 2015.

20. Sanidas E., Shih Y. (2010): Comparison of Revealed Comparative Advantage Indices with Application to Trade Tendencies of East Asian Countries, 9th Korea and the World Economy Conference, New Economic Order after the Global Financial Crisis, Incheon, Korea, (available at: http://www.akes.or.kr/).

21. Torok, A., Jambor, A. (2012): Changes in Agri-Food Trade of the New Member States since EU Accession-A Quantitative Approach, IAAE of Agricultural Economists, Triennial Conference, Foz do Iguaçu, Brazil, 2012, pp. 1-19. (available at: https:/www. researchgate.net/).

22. Methodology of statistics in international trade, Serbian Statistical Office, Belgrade, 
Serbia (available at: http://webrzs.stat.gov.rs/).

23. Statistical Paper - Standard International Trade Classification (SITC), Rev. 4, Series M No.34/Rev.4, United Nations Statistic Division (UNSTAT), 2006, NY, USA (available at: http://unstats.un.org/).

24. Strategy of Agriculture and Rural Development of Republic of Serbia 2014-2020, Ministry of Agriculture and Environmental Protection of Republic of Serbia, 2014, Belgrade, Serbia (available at: http://uap.gov.rs/).

25. User guide on European statistics on international trade in goods, Eurostat, 2014 edition, Luxembourg (available at: http://ec.europa.eu/).

26. Utkulu, U., Seymen, D. (2004): Revealed Comparative Advantage and Competitiveness: Evidence for Turkey vis-à-vis the EU/15, European Trade Study Group $6^{\text {th }}$ Annual Conference ETSG, Nottingham, UK (available at: http://www.etsg.org/).

27. Vollrath, T.L. (1991): A Theoretical Evaluation of Alternative Trade Intensity Measures of Revealed Comparative Advantage, Weltwirtschaftliches Archiv, Vol.127, No.2, 265280, Springer, NY, USA (available at: http://www.jstor.org/stable/40439943).

28. Vollrath, T.L. (1989): Competitiveness and Protection in World Agriculture, Agricultural Information Bulletin No. 567. U.S. Dept. of Agriculture, Economic Research Service. Washington, D.C., USA (available at: http://naldc.nal.usda.gov/).

29. Yeats, A.J. (1985): On the appropriate interpretation of the revealed comparative advantage index: implications of a methodology based on industry sector analysis, Weltwirtschaftliches Archiv, Vol. 121, No. 1, pp. 61-73 (available at: http://www.jstor. org/stable/40439288).

30. Qineti, A., Rajcaniova, M., Matejkova, E. (2009): The competitiveness and comparative advantage of the Slovak and the EU agri-food trade with Russia and Ukraine, Agric. Econ.-Czech, Vol. 55, No. 8, pp. 375-383, Czech Academy of Agricultural Sciences, Prague, Czech Republic (available at: http://www.agriculturejournals.cz/).

31. Zakon o potvrđivanju Sporazuma o stabilizaciji $i$ pridruživanju između evropskih zajednica i njihovih članica, sa jedne strane i Republike Srbije, sa druge strane, Službeni glasnik RS-Međunarodni ugovori, br. 83/2008, Beograd, Srbija

32. Zakon o potvrđivanju Prelaznog sporazuma o trgovini i trgovinskim pitanjima između Evropske zajednice, sa jedne strane, i Republike Srbije sa druge strane, Službeni glasnik RS-Međunarodni ugovori, br. 83/2008, Beograd Srbija 


\title{
TRŽIŠNO ORIJENTISANI PRISTUP UOČENE KOMPARATIVNE PREDNOSTI U MEĐUNARODNOJ TRGOVINI
}

\author{
Boris Kuzman ${ }^{7}$, Milan Stegić ${ }^{8}$,Jonel Subic ${ }^{9}$
}

\begin{abstract}
Rezime
Tržišno orijentisana relativna komparativna prendost (MORTA) predstavlja nov pristup široko prihvaćenog modela uočene komparativne prednosti (RCA) koji je prezentovan po prvi put u ovom radu. Primenjeni model je korišćen u analizi agro-industrijske trgovine u cilju uočavanja nivoa promena relativne komparativne prednosti između EU i Srbije pre i tokom implementacije Sporazuma o stabilizaciji i pridruživanju sa EU (2004-2013) na bazi podataka Eurostat-a i podataka Republičkog zavoda za statistiku Republike Srbije. Analiza teži da prikaže da li su Srbija i EU, svaka na svojoj strani, bile sposobne da iskoriste prednosti trgovinske liberalizacije, posebno u relativnom smislu. Rezultati istraživanja pokazuju da Srbija, u smislu liberalizacije trgovinskih odnosa sa EU, uspeva da obezbedi rast proizvoda sa relativnom komparativnom trgovinskom prednošću, dok sa druge strane EU ne uspeva da u većoj meri koristi preferencijalni status u trgovini sa Srbijom.
\end{abstract}

Ključne reči: tržišno orijentisana uočena komparativna prednost, agro-industrijska trgovina, EU, Srbija

7 Docent, dr Boris Kuzman, Institut za ekonomiku poljoprivrede, Ulica Volgina br. 15, 11060 Beograd, Srbija, Telefon: +381 63590 129, E-mail: kuzmanboris@yahoo.com

8 Mr. Milan Stegić, doktorant, Fakultet za ekonomiju i inženjerski menadžment, Ulica Cvećarska br. 2, 21000 Novi Sad, Srbija, Telefon: +381 638998 804, E-mail: stegicmilan@gmail.com

9 Profesor, dr Jonel Subić, Institut za ekonomiku poljoprivrede, Ulica Volgina br. 15, 11060 Beograd, Srbija, Telefon: +381 63 296111, E-mail: jonel_s@iep.bg.ac.rs 